Dariusz Tabor CR

\title{
Wizerunki maryjne XIV i XV wieku na ziemiach polskich. Studium z ikoniki i chrystologii
}

Kultura religijna, duszpasterstwo i duchowość XIV i XV stulecia przyniosły mnogość przedstawień Matki Boskiej z Jezusem. Na ziemiach polskich pojawiło się kilka charakterystycznych typów ikonograficznych, które charakteryzują się wyrazistymi cechami formalno-stylistycznymi. Jednakże każdy z tych typów ikonograficznych pełnił określoną funkcję oraz niósł treści myślowe i duchowe. Nie jest łatwo odczytać pierwotne przeznaczenie, a w konsekwencji przekaz i orędzie tych wizerunków, pozbawione są one bowiem swego pierwotnego kontekstu, przeniesione w miejsce pierwotnego przeznaczenia. Typ ikonograficzny odczytywany jest w wielości realizacji, które się zachowały. Możliwe jest więc odkrycie najbardziej istotnych elementów formalnych, które mogą stanowić o wizualnym komunikacie treści.

W niniejszym przedłożeniu zostaną przeanalizowane trzy typy ikonograficzne pojawiające się w drugiej połowie XIV wieku oraz w XV wieku na ziemiach polskich. Są to Madonna na Lwach, Piękna Madonna oraz Hodegetria.

Wymienione tematy czy typy ikonograficzne były przedmiotem badań.

Zofia Białłowicz-Krygierowa jest autorką obszernego artykułu poświęconego środowisku, w którym powstawały Madonny 
na Lwach. Sformułowała ona pojęcie „krąg Mistrza Madonn na Lwach”. Określiła też terytorialny zasięg rzeźb tego kręgu, podjęła próbę określenia genezy stylu grupy i zwróciła uwagę na charakterystyczne cechy stylistyczne Madonny ze Skarbimierza ${ }^{1}$. Ostatnio wielu badaczy zajmowało się tymi rzeźbami, skupiając się na typie ikonograficznym, jego funkcjach społecznych i na jakości wizualnej².

Relacjonując badania na temat pięknych Madonn, należy najpierw zwrócić uwagę na obszerne dzieło Carla Heinza Clasena ${ }^{3}$. Istnieje zresztą wiele nowszych prac, których autorzy zastanawiali się nad genezą typu ikonograficznego i stylu, jego cechami charakterystycznymi i wyróżniającymi oraz zasięgiem terytorialnym i warsztatem powstania. Badania takie podejmowali Janina Kruszelnicka, Andrzej Olszewski, Janusz Kębłowski, Zygmunt Kruszelnicki, Michael V. Schwarz, Wojciech Marcinkowski, Monika Jakubek-Raczkowska ${ }^{4}$.

1 Z. Białłowicz-Krygierowa, Ze studiów nad kregiem Madonn na Lwach. Motyw i system, w: Z dziejów sztuki śląskiej, red. Z. Świechowski, Warszawa 1978, s. 240-274.

2 R. Suckale, Die „Löwenmadonna”, ein politischer Bildtyp aus der Frühzeit Kaiser Karls IV?, w: tenże, Das mittelalterliche Bild als Zeitzeuge. Sechs Studien, Berlin 2002, s. 172-184; M. Bartlová, Trůnící madony na lvech w: Śląski Czechy. Wspólne drogi sztuki. Materiaty konferencji dedykowane Profesorowi Janowi Wrabecowi, red. M. Kapustka, A. Kozieł, P. Oszczanowski, Wrocław 2007, s. 35-47; A. Mudra, Madona ze Skarbimierze a otázka role českého sochařství a malírstvi při utvárení slezsko-pomořského stylu madon na lvu, w: Ślq̨ski Czechy, s. 49-61; R. Kaczmarek, Iluzja przestrzeni: Madonna „ze Skarbimierza” - krag Madonn na Lwach w: tenże, Italianizmy. Studia nad recepcją gotyckiej sztuki włoskiej w rzeźbie Środkowo-Wschodniej Europy (koniec XIII - koniec XIV wieku), Wrocław 2008, s. 227-234.

3 C.H. Clasen, Der Meister der Schönen Madonnen. Herkunft, Entfaltung und Umkreis, Berlin-New York 1974.

4 J. Kruszelnicka, Dawny ołtarz Pięknej Madonny Toruńskiej, „Teka Komisji Historii Sztuki" IV (1968), s. 5-85; A.M. Olszewski, Niektóre zagadnienia stylu międzynarodowego w Polsce, w: Sztuka i ideologia XV wieku. Materiały Sympozjum Komitetu Nauk o Sztuce PAN, Warszawa, 1-4 grudnia 
Hodegetrie gotyckie budziły od dawna zainteresowanie badaczy. Najwięcej uwagi poświęcano Hodegetrii Jasnogórskiej, lecz rozszerzano zakres badań o pozostałe obrazy tego typu ${ }^{5}$. Ostatnie lata przyniosły monumentalne, trzytomowe wydawnictwo dokumentujące gotyckie Hodegetrie Małopolski i Górnego Śląska. Jest to publikacja katalogowa zawierająca nie tylko dogłębnie opracowane noty katalogowe, ale również szereg krytycznych studiów ${ }^{6}$.

1976, red. P. Skubiszewski, Warszawa 1976; J. Kębłowski, Dwie antytezy w sprawie tzw. Pięknych Madonn, w: Sztuka ok. 1400. Materiały Sesji Stowarzyszenia Historyków Sztuki, Poznań, listopad 1995, t. 1, red. T. Hrankowska, Warszawa 1996, s. 165-185; Z. Kruszelnicki, Piękne Madonny - problem otwarty, „Teka Komisji Historii Sztuki” VIII (1992), s. 31105; M.V. Schwarz, Piękna Madonna jako kompleksowa forma obrazowa. Zarys problematyki, „Dzieła i Interpretacje” 1 (1993), s. 87-93; W. Marcinkowski, Co to jest Piękna Madonna? Uwagi o wzajemnym powiq̨zaniu formy, ikonografii i funkcji w sztuce późnogotyckiej, w: Prawda i twórczość, red. M. Kapustka, Wrocław 1998, s. 39-53; W. Marcinkowski, Sztuka około roku 1400 - spór o pojęcia, w: Magistro et amico amici discipulique. Lechowi Kalinowskiemu w osiemdziesięciolecie urodzin, red. J. Gadomski, Kraków 2002, s. 51-62; M. Jakubek-Raczkowska, Uwagi o znaczeniu tzw. Pięknych Madonn w sztuce i religijności państwa zakonnego w Prusach, „Acta Universitatis Nicolai Copernici. Zabytkoznawstwo i Konserwatorstwo" XL (2011), s. 39-94.

5 T. Mroczko, B. Dąb, Gotyckie Hodegetrie polskie, „Średniowiecze” 3 (1966), s. 18-74; E. Śnieżyńska-Stolot, Geneza, styl i historia obrazu Matki Boskiej Częstochowskiej, „Folia Historiae Artium” 9 (1973), s. 5-42; A. Różycka-Bryzek, J. Gadomski, Obraz Matki Boskiej Częstochowskiej w świetle badań historii sztuki, „Studia Claromontana” 5 (1984), s. 27-52; E. Śnieżyńska-Stolot, Kult italo-bizantyjskich obrazów maryjnych w Europie środkowej w wieku XIV, „Studia Claromontana” 5 (1984); J. Gadomski, Imagines Beatae Mariae Virginis Gratiosae, Malopolski typ Hodegetrii z XV wieku, „Folia Historiae Artis” 22 (1986), s. 29-48; A. Różycka-Bryzek, Obraz Matki Boskiej Częstochowskiej: pochodzenie i dzieje średniowieczne, „Folia Historiae Artium” 26 (1990), s. 5-26.

6 Prolegomena do badań nad obrazami Hodegetrii typu krakowskiego, red. J. Gadomski, Kraków 2014; Hodegetrie krakowskie, red. M. Schu- 
Powyżej wymienione publikacje dokumentują rozległy stan wiedzy na temat analizowanych $\mathrm{w}$ niniejszym przedłożeniu przedstawień. Brakuje jednak badań teologicznych ich aspektu wizualnego. Chodzi bowiem o relację Maryi i Chrystusa - zarówno formalną, wizualną, jak i teologiczną oraz duchową. Najważniejszym chyba pytaniem, jakie się rodzi w tym kontekście, jest pytanie o miejsce i rolę Chrystusa w całym obrazie. Aby rozwiązać te problemy i odpowiedzieć na powyższe pytanie, konieczne jest zastosowanie odpowiedniego narzędzia. Wydaje się, że będzie nim ikonika Maksa Imdahla ${ }^{7}$. Badacz ten wyszedł od ikonologicznego rozpoznania tematu obrazu, czyli analizy ikonograficznej. Określenie typu ikonograficznego, czyli tematu, miało prowadzić dalej do rozpoznania w nim zasadniczych linii umysłowych i duchowych czasu powstania obrazu. Imdahl uznał jednak, że samo określenie tematu zaciera pewne istotne cechy obrazu. Rozróżnił więc dwa rodzaje widzenia: widzenie rozpoznające, zasadzające się na odkryciu tematu obrazu, oraz widzenie widzące, które w obrazie o określonym temacie odkrywa zapoznane dotychczas jakości formalne oraz cechy struktury wizualnej. Temu mają służyć dwa pojęcia - dwuwymiarowe pole obrazu oraz linie pola obrazowego, odkrywane w tkance formalnej i ikonograficznej. Można mieć zastrzeżenia do zasadności stosowania tych pojęć i odpowiadających im operacji wobec rzeźby, która jest wszak trójwymiarowa. Jednakże sposób odbierania rzeźby średniowiecznej, który często dokonuje się tylko z jednej strony - od frontu, pozwala przyjąć założenia o dwuwymiarowości przedstawienia rzeźbionego i podjąć poszukiwania linii pola.

ster-Gawłowska, M. Lempart-Geratowska, t. 1: 1400-1450, Kraków 2015; t. 2: 1450-1490, Kraków 2017.

7 M. Imdahl, Giotto. Arenafresken: Ikonographie - Ikonologie - Ikonik, München 1996; tenże, Giotto: z zagadnień ikonicznej struktury sensu, „Artium Questiones" IV (1990), s. 103-122. 


\section{Madonna i lwy}

Wyjątkowa rzeźba, jaką jest Madonna na Lwach, określana dotychczas jako Madonna ze Skarbimierza, powstała około roku $1370-1380^{8}$. Jej niepowtarzalność polega nie tylko na ikonograficznej koncepcji usadowienia lwów jako swoistych "trzymaczy” czy „wsporników” lub wyjątkowych elementów symbolicznych. Owszem, obecność figur lwów, niekiedy komicznych, przywołuje biblijną symbolikę tronu Salomona. Jednakże tym, co budzi zainteresowanie i szczególną uwagę, jest formalna struktura rzeźby tworząca całość wizualnego komunikatu. Madonna odziana w tunikę - suknię oraz płaszcz zarzucony na ramiona i swobodnie spływający na biodra i uda, siedzi na ławie o szerokim, lecz płytkim siedzisku. Istotnie, przestrzeń, w której znajduje się siedzisko, jest bardzo płytka. Lekko wyładowany i profilowany cokół tego siedziska świadczy o płytkości tej przestrzeni. Jest on ważny o tyle, że na nim spoczywają skulone postacie z łbami skierowanymi ku widzowi i flankującymi obie stopy Maryi.

Sposób siedzenia Maryi daje dużo do myślenia. Jej głowa i tułów są skierowane frontalnie do widza, z lekkim, prawie niedostrzegalnym skręceniem korpusu nieco w prawo. Natomiast ułożenie nóg odbiega od konwencji korpusu, zgięte w kolanach nogi skierowane są w prawą stronę, prawa noga położona jest nieco wyżej - Madonna opiera stopę na łbie prawego lwa. Jej lewa stopa jest oparta na cokole ławy, mniej więcej w połowie odległości między łbami lwów. Ostro zakończona ciżma skierowana jest czubkiem w dół. Charakterystyczna jest partia nóg i ich ułożenie. Udo prawej nogi spoczywającej na łbie lwa jest ułożone poziomo, z lekkim skierowaniem ku górze. Udo lewe

8 Gotické madony na lvu: splendor et virtus reginae coeli, výstava Muzeum umění Olomouc - Arcidiecézní muzeum Olomouc, 13.02.-11.05.2014; Bergbau- und Gotikmuseum Leogang, 5.06.-31.08.2014, zob. http:// www.muo.cz/AMO/VYSTAVY/probihajici/vystavy-2014-madony-na-lvu/ [data dostępu: 16.10.2019]. 
jest ułożone ukośnie i skierowane ku dołowi. Ta plastyczna różnica jest źródłem dynamicznej gry przestrzennej. Należy jeszcze zwrócić uwagę na wzajemną relację nóg Madonny. Prawa ułożona jest głębiej, lewa ją poprzedza. Wraz z płytką ławą, na której zasiada Madonna, tworzą one płytką przestrzeń. Można nawet mówić o dwóch planach, jednak odległość między nimi jest bardzo mała.

Madonna dzierży berło (częściowo zdefektowane) w lewej dłoni, prawą natomiast podtrzymuje Jezusa, obejmując dłonią Jego biodra. Określenie „Dzieciątko Jezus” nie jest w pełni adekwatne do postaci Chrystusa, który stoi na udzie Matki odziany jedynie w luźną szatę okrywającą Jego biodra i nogi. Wznosi on prawą rękę z wyciągniętymi dwoma palcami - wskazującym i środkowym. Gest ten, powszechnie rozpoznawalny jako błogosławieństwo, należy odczytać nieco szerzej. Jest to mianowicie pewna wersja gestu rozpoczynania przemowy. Należałoby raczej odczytywać go jako znak osoby mówiącej lub rozpoczynającej mowę.

Nieodzowne jest jeszcze uwzględnienie roli aniołów, bo tak należy określić osoby osadzone ponad skulonymi lwami i wspomagające ręce Madonny. Anioł po prawej ujmuje prawą ręką stopy Jezusa, a lewą dłoń Maryi. Anioł po lewej ujmuje dolny kraniec berła i łokieć Maryi. Dwaj aniołowie stanowią niezbędne elementy przedstawienia o charakterze prezentacyjnym, hieratycznym i uroczystym.

Po analizie struktury przychodzi czas na analizę o charakterze ikonicznym. Użycie tego narzędzia do analizy rzeźby może budzić zastrzeżenie. Wszakże ma dotychczas zastosowanie do płaskiej, dwuwymiarowej powierzchni obrazu, jednakże prezentacyjność oraz płaska, prawie dwuwymiarowa struktura przedstawienia upoważniają nas do podjęcia próby odkrycia linii pola obrazowego. Gdzie przebiegają najważniejsze linie, które decydują nie tylko o kompozycji obrazu, lecz też o zawartości treściowej i położonych akcentach? 
Pierwszymi liniami, jakie narzucają się w obserwacji, są linie o przebiegu diagonalnym. Są to linie ud Madonny. Linia prawego uda ma przebieg poziomy, z lekkim jedynie nachyleniem, linia lewego uda biegnie diagonalnie w kierunku prawym ku dołowi. Obie linie pozostają ze sobą w dynamicznej grze. Ich kierunki relacji opozycji i przeciwstawienia stwarzają wrażenie dramatycznego przesuwania akcentów - z górnego ku dolnemu. Struktura ta, dwukierunkowa i dynamiczna, kieruje jednak uwagę ku pionowej linii, której obie stają się bazą. Jest nią statyczna i zaakcentowana postać Chrystusa stojącego na prawym udzie Madonny. Zestawienie diagonalnych linii dynamicznych oraz pionowej linii statycznej przynosi nieoczekiwany rezultat, dominująca okazuje się bowiem struktura pionowa. Ona wysuwa się i przyjmuje pozycję nadrzędną w stosunku do dwóch linii, które stają się jej podłożem i bazą.

Niezależne od tej bazy wydają się jeszcze dwie inne linie diagonalne. Chodzi o wysunięte ręce anioła klęczącego na korpusie lwa. Lewa ręka wznosi się prawie poziomo i chwyta prawą dłoń Matki podtrzymującej syna. Jest ona pionowa $z$ lekkim nachyleniem. Linia lewej ręki, diagonalna, skierowana w prawo ku górze, ujmuje stopy Chrystusa. Obie linie są podporządkowane pionowej linii postaci Chrystusa, dominują jednak nad pionową linią korpusu anioła.

Zadziwiające jest to, że podobna struktura, złożona z dwóch diagonalnych linii, pojawia się po drugiej stronie kompozycji. Anioł klęczący na lewym lwie wznosi prawą rękę pionowo ku łokciowi Maryi, a lewą diagonalnie ku dolnej krawędzi berła. Zestaw obu linii jest symetryczny i analogiczny w stosunku do linii po prawej stronie. Jaką rolę spełniają te linie? Otóż są one podporządkowane innej pionowej linii, mianowicie linii berła, nieco jedynie przechylonego w prawo. Są więc dwie pionowe, dominujące linie - linia Chrystusa i linia berła, których nadrzędne role zaczynamy odkrywać. Nasuwa się jednak pytanie: co z pionową linią korpusu Madonny, która przy pobieżnym oglądzie 
wydaje się centralna i dominująca? Korpus Matki Jezusa określa pionowa linia o wysokości większej niż wysokość linii Jezusa czy berła. Czy ona jest tu najważniejsza i podstawowa?

Zwróćmy uwagę, że ta linia zakończona jest linią głowy - skierowanej lekko w prawo ku Chrystusowi. Mocny pion tej struktury został zredukowany przez to pochylenie. Na pytanie o relacje trzech pionów oraz ich role odpowiedzią może być sposób umieszczenia dwóch bocznych linii - linii Chrystusa oraz linii berła. To ostatnie mieści się w obrębie korpusu Maryi na jego tle. Ten pierwszy - pion Chrystusa, jest nieco odseparowany od korpusu i ujawnia się w wolnej przestrzeni na neutralnym tle. Sytuację jego pionu możemy opisać słowem „ekspozycja” albo ostentatio. Tę ekspozycję wzmacniają zarówno skosy ud Matki, jak i diagonale rąk anioła po prawej stronie, które jeszcze mocniej i bardziej zdecydowanie niż skosy lewego anioła podkreślają pion berła.

Pierwszym nasuwającym się wnioskiem analizy ikonicznej jest to, że cała struktura linii pola służy eskpozycji, wyakcentowaniu i ukazaniu Chrystusa. Stoi On na prawym udzie Matki w pozie hieratycznej z gestem retorycznym. Należy zwrócić uwagę na Jego ubiór. Jego biodra i nogi okryte są swobodną draperią, natomiast tors jest nagi. Odnajdujemy tu dwoistość - okrycie szatą i nagość. Szata określa godność i nadprzyrodzoność, w konsekwencji więc bóstwo. Nagość oznacza ogołocenie Syna Bożego, czyli wcielenie i człowieczeństwo.

Oprócz ubioru swoistą funkcję pełni berło. Trzymane przez Matkę jest symbolem panowania, godności królewskiej. Jednak od razu nasuwa się pytanie, czy jest to godność królewska Matki czy Syna? Wszystko, ława tronowa, uroczyste odzienie, korona wskazywałyby na królewską godność Maryi. Jednak powyższa analiza, w której cała jej postać, poza, układ nóg przygotowuje ostentację Syna - Boga i Człowieka, zdają się wskazywać na berło jako pendent stojącego Chrystusa i symbol Jego statusu.

Wiele może powiedzieć próba rekonstrukcji pierwotnego środowiska analizowanej rzeźby. Ze względu na swą płytkość, 
wykazaną powyżej właściwie dwuwymiarowość, można domniemywać, że była ona przeznaczona do oglądania tylko z jednej strony, czyli do oglądu frontalnego przez widza. Jako taka mogła stanowić wypełnienie środkowej, najważniejszej kwatery retabulum szafiastego. Takie retabulum było otwierane tylko w najważniejsze uroczystości roku liturgicznego. Sytuację, w której przedstawienie Maryi prezentującej Jezusa - Boga i Człowieka, traktowane jest jako wyjątkowe i uroczyste, a jego ogląd ograniczony jest do niektórych jedynie dni roku liturgicznego, można określić mianem epifanii. Wprowadza to dodatkowy czynnik oddziaływania na widza i wizualizacji podstawowej prawdy o bóstwie i człowieczeństwie Chrystusa.

\section{Piękno Matki i piękno Syna: piękno relacji}

Piękna Madonna jest najbardziej znamiennym wytworem stylu międzynarodowego w Europie Środkowo-Wschodniej około 1400 roku. Typ zakorzeniony w środowisku mieszczańskim wyraża jednak wartości tęsknoty i dążenia środowisk arystokratycznych. Wysublimowane piękno kobiece i delikatność stanów emocjonalnych zdają się czymś anachronicznym wobec nabierającego rozpędu realizmu właściwego społecznościom mieszczańskim. Jest to zapewne wyraz tęsknoty za przemijającym już powoli kultem kobiety typowym dla etosu rycerskiego.

Właściwe będzie przeanalizowanie dwóch, najbardziej znamiennych, przykładów Pięknych Madonn. Piękna Madonna wrocławska pochodzi z kościoła św. Elżbiety we Wrocławiu9. Przedstawia młodziutką kobietę w postawie stojącej. Jej sylwetka okryta jest sutym, bogatym i masywnym płaszczem, który okrywa biodra i partię nóg oraz jest przewieszony na lewym

9 W. Marcinkowski, Co to jest Piękna Madonna?, s. 40n.; Piękna Madonna z Wrocławia, MNW Cyfrowe, www.cyfrowe.mnw.art.pl/dmuseion/ [data dostępu: 1.09.2019]. 
przedramieniu Maryi. Delikatna, dziewczęca twarz Matki zwrócona jest w lewo nieco ku dołowi, ku Dzieciątku - na całkowicie nagim niemowlęciu spoczywającym na dłoni i przedramieniu Jej lewej ręki. Dzieciątko przedstawione jest w pozycji diagonalnej i frontalnej w stosunku do widza. Jego korpus i klatka piersiowa są widoczne w całości, jedynie lewa nóżka jest nieco ugięta w kolanie i skierowana w lewo. Jest ona podtrzymywana smukłą dłonią Matki. Należy jednak zwrócić uwagę na relację rąk Maryi i Dzieciątka. Maryja, trzymając przedramię poziomo, wysuwa ku Jezusowi prawą dłoń, w której trzyma jabłko. Jezus, mając ramię ułożone poziomo i przedramię ułożone pod kątem prostym w stosunku do ramienia, dotyka jabłka prawą dłonią. Analogicznie ułożona jest lewa ręka Jezusa - ramię i przedramię tworzą kąt prosty. Pozioma dłoń Maryi i pionowe przedramię Syna spotykają się w punkcie jabłka i tworzą razem kąt prosty. Jabłko staje się elementem newralgicznym, jednak nie centralnym i najważniejszym.

Nie należy lekceważyć dolnej partii rzeźby. Inna masa draperii spływa pionowo spod lewej dłoni Maryi w postaci kaskady wstępujących rurkowatych fałd. Draperia płaszcza po prawej stronie została uformowana w potężne, głębokie fałdy w kształcie litery V i łagodnych łuków. Oba fałdowania mają znaczenie dla wyrazu i orędzia całości.

Również w przypadku tej rzeźby nasuwają się wątpliwości co do zasadności użycia narzędzi ikonicznych. Jest to rzeźba pełnoplastyczna, choć jej oglądu dokonywano z trzech stron. Jednakże zasadnicze elementy struktury plastycznej są widoczne od frontu. Obserwator ujmuje to wszystko, co zawarte jest w dwóch wymiarach płaskorzeźby, która pierwotnie była dostawiona do tylnej ścianki szafy ołtarzowej, dlatego można podjąć próbę identyfikacji linii pola obrazowego.

Zasadniczymi liniami, jakie nasuwają się odbiorcy, jest zespół koncentrycznych fałd po prawej - łukowych i w kształcie litery V. Jest to zespół spiętrzonych segmentów, które stanowią 
mocne oparcie dla prawej dłoni Madonny. Antytezą tego zespołu jest pionowa linia zidentyfikowana w kaskadzie rurkowatych fałd do lewej. Biegnie ona ku postaci Dzieciątka. Nie te linie budzą jednak największą uwagę. Przyciąga ją skomplikowany konglomerat krótkich linii w obszarze rąk Maryi oraz postaci nagiego niemowlęcia. Najbardziej wyrazista jest tutaj pozioma, zdecydowana linia prawej ręki Matki. Styka się ona za pośrednictwem malej bryły jabłka z pionową linią prawego przedramienia Jezusa, który od góry bierze jabłko palcami. Ta krótka linia znajduje kontynuację w poziomej linii prawego ramienia. Układ lewej ręki Dzieciątka jest analogiczny do układu ręki prawej. Jej ramię jest poziome, a prostopadłe do niego przedramię - pionowe. Obie ręce małego Jezusa nadają korpusowi tej postaci symetrii. Nie te linie jednak, choć mające swe znaczenie, decydują o relacjach osób i wyrażeniu określonych wątków treściowych. Krótkie odcinki ramion i przedramion zbiegające się pod kątem prostym flankują diagonalną linię, skierowaną w lewo ku górze ciała Dzieciątka Jezus. Ta właśnie linia jest drugą, która charakteryzuje się wyrazistością i statyką, mimo delikatnego zaprzeczenia jej poprzez przesunięcie lewej nóżki niemowlęcia. Co bardziej interesujące, druga mocna linia, czyli linia przedramienia i dłoni Matki, wchodzi z tą linią w relację i te linie decydują o jakości i dynamice struktury linearnej w partii klatki piersiowej Madonny.

Odczytujemy, że linia pozioma zmierza w kierunku diagonalnej linii Dzieciątka. Maryja wyraźnie kieruje wzrok widza i proces odbioru ku Jezusowi. Szczególną rolę odgrywa tu jabłko - symbol integrujący: Maryja, nowa Ewa, wręcza jabłko nowemu Adamowi. Jabłko niesie symbolikę męki Chrystusa. Ten wątek treści jest znany, lecz nabiera on jeszcze większego znaczenia i wyrazistości w kontekście analizy ikonicznej.

Dla pełni struktury i treści zwróćmy uwagę na jeszcze jedną linię. Tworzy ją przedłużenie linii symetrii twarzy Maryi pochylającej się ku Jezusowi. Zbiega ona diagonalnie ku dołowi 
w prawo i kończy bieg na ciałku Jezusa. Dzieciątko Jezus poddane jest więc ekspozycji, a kierują ku niemu dwie linie. Ważne jest to, że tors małego Jezusa jest frontalnie skierowany ku widzowi.

Piękna Madonna z Torunia (ok. 1390) przedstawia młodą kobietę w pozie stojącej, otuloną potężną, obfitą i masywną draperią płaszcza przesłaniającego partię nóg i bioder i przewieszonego $z$ prawej strony ${ }^{10}$. Draperia po lewej ukształtowana jest w trzy łukowe, głębokie i mocne fałdy w kształcie segmentów łuków. Z prawej spływa bogata girlanda rurkowych fałd rozszerzająca się ku dołowi. Lewą ręką Madonna trzyma Dzieciątko Jezus. Jej dłoń podtrzymuje lewe biodro, udo i podudzie Jezusa. Dzieciątko ma korpus ułożony diagonalnie w lewo ku górze. Jego prawa nóżka zwisa swobodnie ku dołowi, lewa nóżka ugięta jest w kolanie. Ta ostatnia nadaje postaci dynamizm. Dynamiczne są również rączki, ponieważ łagodnymi łukami otaczają z dwóch stron prawą dłoń Matki podającej jabłko. Maria kieruje twarz ku Dzieciątku, pochylając głowę delikatnie w lewo ku dołowi.

Przebieg podstawowych linii jest w wielu sektorach zbliżony do przebiegów w polu Madonny wrocławskiej. Dolne partie dominują dwie linie segmentowe $\mathrm{z}$ lewej oraz pionowa linia girlandy z prawej. Poziome przedramię i dłoń Maryi jest linią decydującą i sprawczą. Dochodzi do diagonalnej linii korpusu Jezusa i wskazuje w ten sposób kierunek doprowadzający do Dzieciątka. Jest to linia statyczna, trwała i mocna mimo dynamizmu linii łukowych. Odkrywamy również linie będące przedłużeniem osi symetrii twarzy Matki. Tak więc dwie linie: pozioma dłoni oraz diagonalna twarzy, wskazują wyraźnie na linię diagonalną ciała Chrystusa.

Obie Piękne Madonny - wrocławska i toruńska - mają zasadniczą funkcję wizualną. To ekspozycja Dzieciątka Jezus. Podstawowym wyznacznikiem tej ekspozycji jest diagonalne ułożenie

${ }^{10}$ M. Jakubek-Raczkowska, Uwagi o znaczeniu tzw. Pięknych Madonn w sztuce i religijności państwa zakonnego w Prusach, s. 42. 
ciała Dzieciątka oraz frontalność Jego torsu, bardziej wyraźna u Madonny wrocławskiej. Pewnym oryginalnym wkładem jest tutaj jabłko - symbol integrujący obie osoby, ustanawiający dialogiczną relację. Maria, przekazując jabłko jako nowa Ewa, dokonuje profetycznego gestu, zapowiadając zbawczą mękę swego Syna. Dodatkowym elementem jest melancholijny smutek Jej twarzy. Jednak należy z naciskiem podkreślić, że wizualna struktura i kompozycja rzeźb, wykazana w zespole linii pola obrazowego, nastawiona jest na uwidocznienie, ekspozycję i doprowadzenie poszukującego wzroku widza do postaci Chrystusa. Nagość Dzieciątka nie jest przypadkowa. Ujawnia tajemnicę wcielenia, które określane jest jako ogołocenie syna Bożego z bóstwa.

\section{Hodegetria - Prowadząca}

Bizantyńska geneza typu ikonograficznego i jego początki w sanktuarium Ton Hodegon w Konstantynopolu są wyczerpująco opracowane. Prowadzone były również badania nad oddziaływaniem tego wzorca na maryjne obrazy Europy Środkowo-Wschodniej. Nam jednak chodzi o grupę Hodegetrii z pierwszej połowy XV wieku oraz początków drugiej połowy tegoż stulecia, które odznaczają się swoistą formą i zasobem ikonograficznym. Rozmieszczone są one w Małopolsce i na Górnym Śląsku. Jako przykład do analizy została wybrana Hodegetria z kościoła św. Zygmunta i św. Jadwigi w Kędzierzynie-Koźlu ${ }^{11}$.

Obraz tablicowy przedstawia Madonnę w półpostaci okrytą błękitnym płaszczem, który okrywa również głowę i jest spięty na wysokości obojczyków bogatą czworokątną fibulą. Dwie krawędzie płaszcza poniżej fibuli biegną łagodnymi łukami w lewo ku dołowi. W dolnej partii przedstawienia płaszcz

${ }^{11}$ Hodegetria, Kędzierzyn-Koźle, w: Hodegetrie krakowskie, t. 1, s. 120-122. 
tworzy dwie krawędzie o przebiegu łagodnego łuku biegnącego od strony prawej w górze, od przegubu prawej ręki Maryi ku stronie lewej u dołu. Dwie linie łukowe uzupełnione są o małą fałdkę po prawej stronie u dołu. Lewą ręką Madonna obejmuje biodra Jezusa. Jest to postać zminiaturyzowanego dorosłego z młodzieńczą twarzą. Jezus jest ubrany w luźną brokatową tunikę z ornamentami w kształcie granatu. Chrystus spoczywa na dłoni i przedramieniu Matki w postaci siedzącej z wyprostowanym tułowiem oraz luźno opuszczonymi nogami i skośnie ułożonymi udami. Prawą rękę wznosi w geście oratorskim, lewą dłoń trzyma na wolumenie księgi opartej na udzie. Prawa ręka Maryi z poziomym przedramieniem skierowana jest ku Jezusowi. Ten gest jest znamienny i on dominuje w całej strukturze obrazu. Jest jeszcze inna dominanta. Jest nią fibula spinająca poły płaszcza. W pobieżnym oglądzie ona stanowi punkt centralny.

Płaszczyzna obrazu i linearne jakości stylistyczne sprzyjają analizie ikonicznej. Delikatne, łagodne linie krawędzi płaszcza spływające łukami nie mają wyrazistości decydującej. Tworzą pewną strukturę, która wspomaga coś bardziej wyrazistego, z jednym jednak zastrzeżeniem. Dwie linie krawędzi płaszcza spływające od fibuli w lewo ku dołowi kierują się wyraźnie ku postaci Chrystusa, jednak nie są to linie przewodnie. Główną linią, decydującą o strukturze zespołu pozostałych osi oraz o treściach obrazu, jest pozioma linia prawego przedramienia i prawej dłoni Maryi. To dla niej łagodne łuki u dołu stanowią bazę i wsparcie. Ta linia, usytuowana mniej więcej w połowie wysokości obrazu, jest wyrazista, zdecydowana i mocna. Kieruje ona widza ku innemu zespołowi linii, tych opisujących siedzącego Chrystusa. Pierwszą z nich jest linia pionowa tułowia i głowy. Nieco poniżej odkrywamy linię ugiętych nóg. Ta nadaje Mu cech statyczności, dystansu hieratyzmu. Wchodzi ona w relację z poziomą linią ręki Matki. Jest odpowiedzią równie zdecydowaną i silną na skierowany komunikat linii ręki. 
Te dwie linie stanowią o wyrazie i komunikacie Hodegetrii kozielskiej. Bycie i działanie przedstawionej Maryi jest po prostu prowadzeniem do Chrystusa. Matka wskazuje Syna i kieruje wzrok ku Chrystusowi, który nie jest Dzieciątkiem, choć przedstawiono Go w postaci zminiaturyzowanej. Postać Chrystusa uwidacznia Jego człowieczeństwo, lecz Jego ubiór i gesty uwypuklają Jego nadprzyrodzoność, jedyność oraz pierwszeństwo. Syn Człowieczy został przedstawiony jako osoba nauczająca i przekazująca orędzie dobrej nowiny - wizualnymi cechami tego są gest retoryczny i księga.

\section{Chrystus w kontekście wizerunków maryjnych}

Obrazy, które zostały wcześniej przeanalizowane, przedstawiają Maryję, Matkę Jezusa, Bogarodzicę, Matkę Boską. Macierzyństwo Maryi jest zasadniczym rysem każdego typu ikonograficznego. Zestaw atrybutów inny w każdym temacie: obfity płaszcz, ława tronowa, berło, korona, fibula. Wskazują one na wysoką godność i wyjątkowość tej kobiety, Jej królewskość i wybranie. Ze względu na obecność Jezusa można powiedzieć, że wybranie i godność syntetyzują się w tych obrazach w tytule Bogarodzicy.

Wszystko to nie wyczerpuje treści i sposobu oddziaływania na widza tych obrazów. Kluczem do ich odczytania może być obecność Jezusa w strukturze wizualnej oraz Jego rola w każdym $\mathrm{z}$ wizerunków.

Przeprowadzone analizy każą wykluczyć pewne stwierdzenia, które mogą się nasuwać przy pobieżnym oglądzie. Chrystus w każdym z przedstawień nie jest ani osobą centralną, ani dominującą, ani nawet skupiającą uwagę. Co więcej, obserwacje mówiące o tym, że Jezus jest podporządkowany Matce oraz usytuowany w bocznych sektorach kompozycji, będą jak najbardziej trafne. Konstatację o "chrystocentryczności” wizerunków należy więc odrzucić. Postać Jezusa w stosunku do Maryi jest znacznie 
pomniejszona, więc to Jej postać dominuje w polu obrazowym. Jaka jest więc rola Chrystusa?

Przeprowadzone analizy ikoniczne przekonują nas, że zasadnicze linie pola obrazowego tworzą drogę odbioru obrazu, która prowadzi do postaci Chrystusa. Jest to pewna droga, którą musi przejść widz ze swoją zdolnością percepcyjną, nie zawsze wykształconą i sprawną, aby dotrzeć do Jezusa, który nie okazuje się elementem centralnym, uwypuklonym i danym do natychmiastowego odbioru, ale punktem dojścia, zakończeniem pewnego procesu, który może przebiegać nie bez przeszkód i zakłóceń. Ten proces mógł się dokonywać w sytuacji epifanii, jak w przypadku Madonny na Lwach przy otwarciu szafy ołtarzowej albo w sytuacji bezpośredniego kontaktu z rzeźbą Pięknej Madonny czy obrazem Hodegetrii.

W tej sytuacji rola Maryi, głównej osoby wizerunku, jawi się jako nieodzowna i konieczna. Ona bowiem swoją pozą, postawą, emocjonalnością oraz atrybutami i gestami prowadzi do Jezusa, ukazuje Go widzowi, odkrywa przed widzem bóstwo i człowieczeństwo Syna oraz pomaga budować z Nim relację. Tworzenie obrazów, w których Maryja prowadzi ku Jezusowi i wskazuje Go widzowi, przy zastosowaniu różnorodnych typów ikonograficznych oraz środków formalnych można nazwać chrystologizacją wizerunków maryjnych. Byłaby to więc tendencja i pewien nurt duchowy teologiczny, ale również plastyczny i wizualny, obejmujący twórczość artystyczną XIV i XV wieku w Europie Środkowej. Należy przeanalizować pozostałe maryjne typy ikonograficzne, nawet przy zastosowaniu ikoniki, aby zweryfikować, czy i w nich nie ujawnia się droga prowadząca do Chrystusa.

Należałoby się zastanowić, jakie przyczyny spowodowały zaistnienie tej tendencji i pojawienie się przeanalizowanych tematów wizualnych. Pierwszą przyczyną, jaka się narzuca, jest odkrycie i doświadczenie człowieczeństwa Chrystusa. Doświadczenie Chrystusa człowieka i Chrystusa niemowlęcia oraz Chrystusa cierpiącego niewątpliwie spowodowało, że stał się 
On bliższym wiernym epoki. To doświadczenie zostało wpisane w kontekst życia codziennego, gdzie ważną rolę odgrywa konkret doświadczany wizualnie oraz codzienne relacje międzyosobowe. Konieczność nawiązywania kontaktów międzyludzkich w środowisku miasta i wsi pozwalała przenieść to doświadczenie na grunt życia religijnego. Istniejące już od dłuższego czasu wizualne doświadczenia, do których należy zaliczyć wzrokowy kontakt z relikwiami, powszechne w XIV i XV wieku widzenie podnoszonej konsekrowanej Hostii, stosowanie obrazów kaznodziejskich czy wizualizacja rzeczywistości nadprzyrodzonych w otwartym ołtarzu szafiastym wpłynąć mogły na powstanie wizerunków, w których Maryja, Matka Jezusa, prowadzi ku wizualnemu doświadczeniu Syna. Niewątpliwa jest również istotna zmiana, jakiej doświadczało społeczeństwo tego czasu, a mianowicie przesuwanie akcentu na osobisty związek z Chrystusem $\mathrm{i}$ indywidualizację doświadczenia religijnego. Wobec tego ostatniego należy zachować ostrożność. Ta przemiana dokonywała się bardzo powoli, a odbiór otwartego ołtarza szafiastego był najpierw doświadczeniem wspólnoty osób zgromadzonych na liturgii świątecznej.

Chrystologizacja wizerunków maryjnych jest więc fascynującym tematem godnym dalszych badań.

\section{St Mary's images of $14^{\text {th }}$ and $15^{\text {th }}$ centuries in Polish regions: studies iniconology and christology}

This paper considers three iconographical types of Mother's of God images. These are Madonna on the lions (Löwenmadonna), Beatiful Madonna with Child (Schönemadonna) and Hodegetria. These images has been objects of research of some scholars. However the visual structures and the relationship between Mother and Child were not sufficiently studied. In order to dis- 
cover this relationship and to read the profound meaning of images we applicate the iconic analysis of Max Imdahl, a particular method of analysis, who take into account the flat surface of image and the lines, which designs its form and its composition.

Madonna on the Lions from Skarbimierz in Silesia 1370-1380 represent Madonna sitting on the throne based on two lions and the Jesus Childe staying on her leg. Two diagonals lines of Madonna's thighs and four diagonals line of Angels's hands design a visual base for another lines who create the nucleus of the representation. These the strong vertical line of Madonna's corps, the line of of Jesus figure standing on her thigh and the line of Madonna's scepters. The structure of these line is modelled in order two focus the figure of Jesus. In fact the figure of Madonna, the submitted angels and lions has been composed in order to visualize the little Jesus.

The Beautiful Madonna form Wroclaw and Beautiful Madonna from Torun depicts a figure of young woman wrapped in a profuse coat looking in the tender relationship on her Child on her left hand and giving him an apple. The diagonal line of the Jesus's corps and the horizontal line of her mother's hand create the most important visual structure which emphasizes the person of Jesus. Another lines, included the line of right hand of Jesus, taking a fruit from Mother's hand and the lines of the monumental folds in the lower part of Madonna's figure serves to highlight the person of Jesus and the principal relationship of Mother with his Child. In fact Madonna point out his Son and shows him to viewers.

Hodegetria from Kędzierzyn-Koźle shows the Madonna in semi figure, wearing a splendid coat and holding Jesus on her left hand. Jesus is a miniaturized adult man wearing a splendid tunic, holding a book and making a rhetorical gesture. The principal lines describe the horizontal line of Madonna's hand pointing Christ and the broken line of sitting Christ's corps. Madonna's gesture evidently guides the attention of viewer to Christ. 
The visual structure of image analyzed above has been created in order to put in emphasize the figure of Christ. So the role of Madonna is to show Jesus child to faithfulls. Consequently we can discover an attitude called the christologisation of Mother's of God images. It is due to experience of human nature of Christ and the tendency to visualization of the Christian mysteries. 